\title{
梁材の力学的性能が柱梁溶接接合部の変形能力に与える影響 に関する実験的研究

\author{
EXPERIMENTAL STUDY ON EFFECT WHICH MECHANICAL PROPERTY \\ OF BEAM MATERIAL GIVES TO DEFORMATION CAPACITY \\ OF BEAM TO COLUMN WELDED CONNECTION
}

\author{
中込忠男*1, 的場 耕*2, 岩田 衛*3 \\ Tadao NAKAGOMI, Kou MATOBA and Mamoru IWATA
}

\begin{abstract}
This paper presented the results of tests which were conducted to investigate the influence of the mechanical property and the charpy absorbed energy at $0^{\circ} \mathrm{C}(\mathrm{vE} 0)$ on deformation capacity of beam to column welded connection. Cyclic loading tests, which experimental parameters were kinds of steel materials and beamends detail (which were the scallop method and non-scallop method), were carried out. The conclusion of this study can be summarized as follows;

1) The deformation capacity of beam to column welded connection is influenced by the mechanical property of the beam flange.

2) When the $v E 0$ of fracture starting point was more than $130 \mathrm{~J}$, the deformation capacity was not influenced by the fracture toughness.

3) Though the specimen of Non'scallop method was superior to the scallop one, in comparison with the estimation of material property, the effect of the beam-ends was small.
\end{abstract}

\author{
Keywords: beamto-column welded connectionmechanical property,fracture toughness, \\ non-scallop method, fracture behavior, deformation capacity \\ 柱梁溶接接合部，機械的性質，䩚性，ノンスカラップ工法，破壊性状，変形能力
}

\section{1.はじめに}

耐震設計基軯の2次設計において、部材の塑性変形能力により構 造物の耐震性を確保することが意図されており、部材が降伏した後 の変形量が重要となる。よって、梁崩壊型の設計がなされている場 合、梁部材の塑性変形能力が重要となる。さて、梁部材には応力勾 配が存在するが、応力勾配を有する部材では、変形能力が素材の降 伏比に依存し、降伏比が大きいほど変形能力が小さいことは、変断

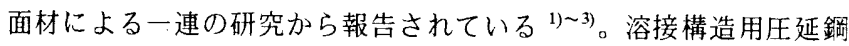
材 (SM 材)、一般構造用圧延鋼材（SS 材）は降伏点の上限に規定 がなく、降伏点にばらつきがあることが報告されている めに、1994 年に制定された JIS G 3136 建築構造用圧延鈮材（SN 材） は降伏点と降伏比の上限が規定されている。

塑性変形が期待される鋼構造柱梁溶接接合部は、地震時に高応力 状態となる箇所であり、材質的、形状的な不連続部の存在により破 壊する危険性が高く、建築鉄骨の柱梁溶接接合部をモデル化した破

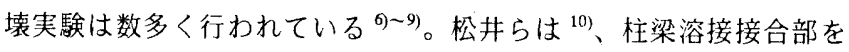
モデル化した試験体を用いた曲げ実験を行い、降伏比が低い方が変 形能力に優れていると報告している。ただし、ノンスカラップ試験 体は座屈により耐力が決定され、スカラッブ試験体は座屈を伴う延 性破壊で破壊している。
1995 年の兵庫県南部地震では、建築鉄骨の梁端接合部に塑性変形 を伴った脆性破壊が確認された ${ }^{11}$ 。梁端部の脆性破壊に影響する因 子の一つに、鋼材のシャルピー衞撃試験による $0^{\circ} \mathrm{C} の$ 吸収エネルギ 一（以下 vEo とする）が考えられる。SM材 (B,C材)、SN 材 (B,C 材）では、vEo の下限值が規定されている。変形能力とシャルピー 衝撃試験による勒性値については、これまでに行われた柱梁溶接接 合部の破壊実験で幾つか報告されている。

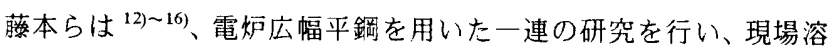
接型の溶接仕口では、柱フランジ材のvEoが50J を下回ると早期に 柱フランジで破壊したと報告している。田淵らは ${ }^{177,18)}$ 、接合部の形 状など様々な因子について実験を行い、接合部の形状が変形能力に 影響を与えること、梁部材の $\mathrm{vEo}$ は変形能力に影響し、勒性值が低 いと変形能力が小さいと報告している。また、それそれの研究で、 vEo が小さい鋼材を用いた試験体においても、梁端ディテールによ つては早期に破断しない場合もある。接合部の変形能力には梁端デ イテール、施工条件、vEo など様々な要素が影響することも指摘し ている。

鋼材の勒性についての研究は建築以外の分野でも行われている。 宮田らは ${ }^{19,20)}$ 、丹周切欠き付丸棒試験片を用いて、破壊勒性の温度 依存性は降伏応力の温度依存性によりほぼ一義的に定まっており、

\footnotetext{
本研究の一部は, 文献21)において発表済みである。

*1 信州大学工学部社会開発工学科 教授. 工博

*2 信州大学工学部社会開発工学科 大学院生.工修

*3 神奈川大学 教授・工博
}

Prof., Dept. of Architecture and Civil Engineering, Faculty of Engineering, Shinshu Univ., Dr. Eng.

Graduate Student, Dept. of Architecture and Civil Engineering, Faculty of Engineering, Shinshu Univ., M. Eng. Prof., Kanagawa Univ., Dr. Eng. 
へき開破壊応力と降伏応力からなるへき開破壊パラメータと破壊勒 性には良い相関があることを報告している。

本研究は、柱梁溶接接合部をモデル化した試験体を用いて、梁に 用いる鋼材の機械的性質と vEo が、接合部の変形能力に与える影 響について検討することを目的とする。

\section{2.実検概要}

\section{1 試験体形状と実験パラメータ}

試験体は柱に熱間成形角形鋼管（STKR490）を使用した工場溶接 接合形式によるト形試験体とした。梁には圧延 H 形鋼 RH-400×400 $\times 13 \times 21$ のフランジ部分を $200 \mathrm{~mm}$ カットして作成した RH-400× $200 \times 13 \times 21$ の A 材, $\mathrm{C}$ 材, $\mathrm{H}$ 材と、溶接組立 $\mathrm{H}$ 形銅 BH- $400 \times 200$ $\times 12 \times 25$ の B 材， E 材，F 材の 6 種類の鋼材を使用した。機械的 性質及び化学成分のミルシート值を表 1 に示す。梁端ディテールは スカラップエ法（スカラップ底のアールは $10 \mathrm{~mm}$ ）とノンスカラッ プエ法とし、エンドタブは全試験体ともスチールタブを用い、溶接 後にスチールタブを削るなどの加工は行っていない。なお BH 材は 先組とし、RH 材とともに開先は機械加工で行った。試験体形状を 図1に示す。

突合せ溶接は溶接ワイヤ YGW11-1.2 $\phi$ を用いて入熱を $35 \mathrm{~kJ} / \mathrm{cm}$ 以 下（最終層は 2 パス $25 \mathrm{~kJ} / \mathrm{cm}$ 以下）とし、パス間温度を管理せずに 連続溶接で行った。なお、梁フランジの突合せ溶接は同一の溶接施 工者によって施工された。6 種類の鋼材を使用したスカラップ試験 体とノンスカラップ試験体についてそれぞれを試験温度 $0^{\circ} \mathrm{C}$ で、A 材を除く 5 銅種のノンスカラップ試験体は常温 $\left(17^{\circ} \mathrm{C} \sim 20^{\circ} \mathrm{C}\right)$ でも

表 1 機械的性質及び化学成分のミルシート值

\begin{tabular}{|c|c|c|c|c|c|c|c|c|c|}
\hline \multirow{3}{*}{ 鋼材 } & \multicolumn{4}{|c|}{ 機械的性質 } & \multicolumn{5}{|c|}{ 化学成分 (\%) } \\
\hline & \multirow{2}{*}{$\begin{array}{c}\text { Y.P. } \\
\left(\mathrm{N} / \mathrm{mm}^{2}\right)\end{array}$} & \multirow{2}{*}{$\begin{array}{c}\text { T.S. } \\
\left(\mathrm{N} / \mathrm{mm}^{2}\right)\end{array}$} & \multirow{2}{*}{$\begin{array}{l}\text { Y.R. } \\
(\%)\end{array}$} & \multirow{2}{*}{$\begin{array}{l}\text { EL. } \\
\text { (\%) }\end{array}$} & $\bar{C}$ & $\mathrm{Si}$ & $\mathrm{Mn}$ & $P$ & $\bar{S}$ \\
\hline & & & & & \multicolumn{3}{|c|}{$\times 100$} & \multicolumn{2}{|c|}{$\times 1000$} \\
\hline $\bar{A}$ & 436 & 549 & 79 & 28 & 15 & 27 & 140 & 15 & 12 \\
\hline B & 349 & 51 & 67 & 2 & 11 & 22 & 124 & 14 & 5 \\
\hline C & 346 & 53 & 65 & 29 & 15 & 37 & 145 & 15 & 7 \\
\hline $\mathrm{E}$ & 390 & 538 & 73 & 29 & 13 & 29 & 129 & 18 & 6 \\
\hline $\mathrm{F}$ & 336 & 522 & 64 & 28 & 13 & 29 & 144 & 11 & 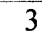 \\
\hline $\mathrm{H}$ & 418 & 539 & 78 & 29 & 13 & 23 & 141 & 25 & 6 \\
\hline
\end{tabular}

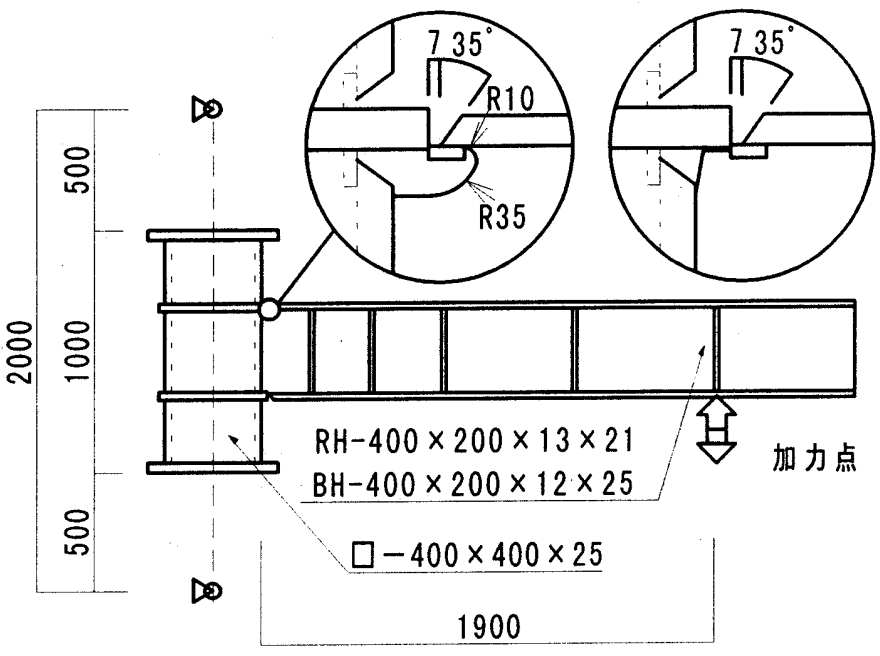

図 1 試験体形状
載荷実験を行った。実験パラメータを表 2 に示す。

$0^{\circ} \mathrm{C} に お け る$ 載荷は、試験体の接合部周辺（梁端部 $500 \mathrm{~mm}$ 程度） とパネルゾーンに冷却容器を取り付け、エタノールと水、ドライア

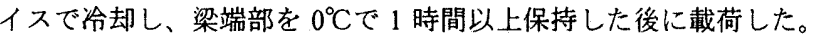
載荷は動的疲労試験機（神奈川大学設置）で、梁部材全断面を有効 として得られる全塑性耐力 (cPp) 時の曲げ変形量 $\mathrm{c} \delta \mathrm{p}$ (ミルシー トの Y.P.を用いた）を基準とした変位制御による正負交番繰返し載 荷とした。なお、制御に用いる梁の変位は、パネル部の变形を測定 (3 箇所測定) して加力点の変位に換算した值を、加力点における 変位計の值から差し引いた值とした。載荷パターンを図 2 に示す。

\section{2 梁に使用する铜材の素村試験}

各鋼材のフランジ母材と突合せ溶接継手による溶接部の材料特性 を調查した。引張試験は母材について、JIS Z2201 14A 号試験片を $\mathrm{C}$ 方向に採取して行った。シャルピー衝撉試験は母材、RH 材のフ イレット部、溶着金属、熱影響部について、JIS Z2202 V ノッチ試 験片を L 方向に採取して行った。熱影響部（ボンド部）の試験片 は、ノッチ先端が溶接金属と母材の溶融境界部より $0.5 \mathrm{~mm}$ 母材側 の位置となるように採取した。

引張試験結果を表 3 に示す。降伏点は $\mathrm{H}$ 材, $\mathrm{A}$ 材が高く、次に $\mathrm{C}$ 材、そしてB 材, E 材, F 材は低い值であった。降伏比は $\mathrm{H}$ 材 $>\mathrm{A}$ 材 $>\mathrm{C}$ 材 $>\mathrm{E}$ 材 $>\mathrm{B}$ 材 $>\mathrm{F}$ 材の順に高い結果となった。C 材, $\mathrm{H}$ 材 は引張試験結果とミルシート值との間に大きな差がある。変位を制 御した $\mathrm{c} \delta \mathrm{p}$ の算出にはミルシート值を採用したが、梁部材の機械 的性質としては引張試験の結果を採用する。

シャルピー衝撃試験結果を表 4 に示す。試験片名のアルファベッ

表 2 実験パラメータ

\begin{tabular}{|c|c|c|c|c|}
\hline 試験体名 & 梁 $\sigma$ & & 梁端"゙ 伃-N & 試験温度 \\
\hline $\mathrm{As} 0$ & $\bar{A}$ & \multirow{3}{*}{$\mathrm{RH}$} & \multirow{3}{*}{ スカラップ } & \multirow{3}{*}{$0^{\circ} \mathrm{C}$} \\
\hline Cs0 & $\mathrm{C}$ & & & \\
\hline $\mathrm{Hs} 0$ & $\mathrm{H}$ & & & \\
\hline Bs0 & B & \multirow{3}{*}{$\mathrm{BH}$} & \multirow{3}{*}{ スカラップ } & \multirow{3}{*}{$0^{\circ} \mathrm{C}$} \\
\hline Es0 & $\mathrm{E}$ & & & \\
\hline Fs0 & $\mathrm{F}$ & & & \\
\hline An0 & A & \multirow{3}{*}{$\mathrm{RH}$} & \multirow{3}{*}{ ノンスカラップ } & \multirow{3}{*}{$0^{\circ} \mathrm{C}$} \\
\hline $\mathrm{Cn} 0$ & $\bar{C}$ & & & \\
\hline $\mathrm{Hn} 0$ & $\mathrm{H}$ & & & \\
\hline $\mathrm{Bn} 0$ & B & \multirow{3}{*}{$\mathrm{BH}$} & \multirow{3}{*}{ ノンスカラップ } & \multirow{3}{*}{$0^{\circ} \mathrm{C}$} \\
\hline En0 & $\mathrm{E}$ & & & \\
\hline Fn0 & $\mathrm{F}$ & & & \\
\hline $\mathrm{Cn} 1$ & $\mathrm{C}$ & \multirow{2}{*}{$\mathrm{RH}$} & \multirow{2}{*}{ ノンスカラップ } & \multirow{2}{*}{$\begin{array}{l}17^{\circ} \mathrm{C} \sim \\
20^{\circ} \mathrm{C}\end{array}$} \\
\hline $\mathrm{Hn} 1$ & $\mathrm{H}$ & & & \\
\hline $\mathrm{Bn} 1$ & B & \multirow{3}{*}{$\mathrm{BH}$} & \multirow{3}{*}{ ハンスカラップ } & \multirow{3}{*}{$\begin{array}{c}17^{\circ} \mathrm{C} \sim \\
20^{\circ} \mathrm{C}\end{array}$} \\
\hline En1 & $\mathrm{E}$ & & & \\
\hline Fn1 & $\mathrm{F}$ & & & \\
\hline
\end{tabular}

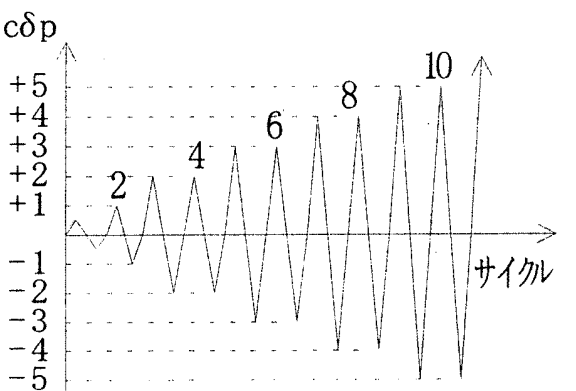

図 2 載荷パターン 
トは鋼材の種類と採取位置を示しており、右添字は $\mathrm{s}=$ 母材、 $\mathrm{f}=$ フィレット、 $\mathrm{h}=$ 熱影響部である。シャルピー衝撃試験結果の遷移 温度は式 1 、式 2 より求めた。

$$
\begin{aligned}
& { }_{\mathrm{v}} \mathrm{E}=\frac{\mathrm{v} \text { Eshelf }}{2}\{1+\tanh \alpha(\mathrm{T}-\mathrm{v} \text { Tre })\} \quad \cdots \text { 式 } 1 \\
& { }_{\mathrm{v}} \mathrm{E} \text { :吸収エネルギー }{ }_{\mathrm{v}} \text { Eshelf:シェルフエネルギー } \\
& \alpha \text { :エネルギー係数 } \quad \mathrm{v} \text { Tre:吸収エネルギー遷移温度 } \\
& { }_{\mathrm{v}} \mathrm{B}=50\{1-\tanh \beta(\mathrm{T}-\mathrm{v} T \mathrm{Ts})\} \quad \cdots \text { 式 } 2 \\
& { }_{\mathrm{V}} \mathrm{B} \text { :脆性破面率 } \quad \beta \text { : 破面係数 } \quad \mathrm{V} \text { Trs:破面遷移温度 }
\end{aligned}
$$

フランジ母材の $\mathrm{vEo}$ は C 材, $\mathrm{E}$ 材および $\mathrm{F}$ 材が高く、 $\mathrm{A}$ 材, $\mathrm{B}$ 材 および $\mathrm{H}$ 材が低い。フィレットの vEo は母材とほぼ等しい值であ った。フランジ母材の vEo が高い $\mathrm{C}$ 材、 $\mathrm{E}$ 材および $\mathrm{F}$ 材はフラン ジの vEo に比べて HAZ の vEo が低く、逆にフランジ母材の vEo が

\begin{tabular}{|c|c|c|c|c|c|c|c|c|}
\hline 鋼材 & $\begin{array}{l}\text { upY.P. } \\
\left(\mathrm{N} / \mathrm{mm}^{2}\right)\end{array}$ & $\begin{array}{l}\text { lowY.P. } \\
\left(\mathrm{N} / \mathrm{mm}^{2}\right)\end{array}$ & $\begin{array}{l}\varepsilon \text { st } \\
(\%)\end{array}$ & $\begin{array}{c}\text { T.S. } \\
\left(\mathrm{N} / \mathrm{mm}^{2}\right)\end{array}$ & $\begin{array}{l}\varepsilon \mathrm{u} \\
(\%)\end{array}$ & $\begin{array}{l}\text { Y.R. } \\
(\%)\end{array}$ & $\begin{array}{l}\text { EL. } \\
(\%)\end{array}$ & $\begin{array}{l}\text { 絞り } \\
(\%)\end{array}$ \\
\hline A & 409 & 391 & 1.29 & 555 & 15.2 & 74 & 28 & 71 \\
\hline B & 332 & 332 & 0.55 & 528 & 16.1 & 63 & 31 & 71 \\
\hline C & 386 & 364 & 1.27 & 548 & 15.6 & 71 & 29 & 77 \\
\hline E & 330 & 322 & 0.80 & 514 & 16.1 & 64 & 33 & 75 \\
\hline$F$ & 318 & 311 & 0.45 & 511 & 15.0 & 62 & 29 & 67 \\
\hline $\mathrm{H}$ & 400 & 374 & 1.44 & 536 & 16.4 & 75 & 31 & 73 \\
\hline Aウエブ & 441 & 414 & 2.01 & 552 & 16.0 & 80 & 30 & 67 \\
\hline Bウェブ & 394 & 372 & 1.20 & 535 & 15.5 & 74 & 29 & 62 \\
\hline Cクエブ & 442 & 416 & 2.31 & 550 & 15.9 & 80 & 30 & 68 \\
\hline Eウエブ & 397 & 375 & 1.31 & 558 & 16.0 & 71 & 28 & 55 \\
\hline Fウェブ & 399 & 382 & 1.39 & 555 & 15.6 & 72 & 27 & 57 \\
\hline $\left.\mathrm{Hウ口}^{\prime}\right)^{\circ}$ & 449 & 408 & 2.29 & 542 & 16.4 & 83 & 32 & 70 \\
\hline
\end{tabular}
低い A 材, B 材および H 材の場合は、HAZ の方がフランジ母材に 比べて vEo が高い。つまり、HAZ は母材に比べて vEo の鋼材によ る差が小さい。

\section{表 3 引張試験結果}

\begin{tabular}{|c|c|c|c|c|c|}
\hline 採取位置 & 試験片名 & $\mathrm{vEo}(\mathrm{J})$ & $\mathrm{vBo}(\%)$ & $\operatorname{Tre}\left({ }^{\circ} \mathrm{C}\right)$ & $\operatorname{Trs}\left({ }^{\circ} \mathrm{C}\right)$ \\
\hline \multirow{6}{*}{ 母材 (s) } & $\mathrm{As}$ & 19 & 88 & 22 & 24 \\
\hline & B s & 34 & 88 & 33 & 34 \\
\hline & $\mathrm{Cs}$ & 286 & 1 & -51 & -48 \\
\hline & Es & 240 & 15 & -39 & -27 \\
\hline & F s & 283 & 6 & -28 & -23 \\
\hline & $\mathrm{Hs}$ & 55 & 78 & 23 & 16 \\
\hline \multirow{6}{*}{$\begin{array}{c}\text { 熱影響部 } \\
\text { (h) }\end{array}$} & $\mathrm{Ah}$ & 199 & 7 & -31 & -28 \\
\hline & $\mathrm{B} \mathrm{h}$ & 160 & 47 & -7 & -1 \\
\hline & $\mathrm{Ch}$ & 250 & 2 & -33 & -33 \\
\hline & $\mathrm{Eh}$ & 200 & 33 & -23 & -13 \\
\hline & $\mathrm{F} \mathrm{h}$ & 260 & 10 & -30 & -27 \\
\hline & $\mathrm{Hh}$ & 130 & 47 & 3 & -2 \\
\hline \multirow{3}{*}{$\begin{array}{c}\text { フィレット } \\
\text { (f) }\end{array}$} & $\mathrm{Af}$ & 24 & 85 & $=$ & - \\
\hline & $\mathrm{C} \mathrm{f}$ & 282 & 0 & - & - \\
\hline & $\mathrm{H} \mathrm{f}$ & 68 & 77 & - & - \\
\hline \multirow{2}{*}{ 溶着金属 } & RH Depo & 80 & 60 & 3 & 8 \\
\hline & BH Depo & 28 & 88 & 51 & 42 \\
\hline
\end{tabular}

upY.P. : 上降伏点 lowY.P. : 下降伏点 $\varepsilon$ st：ひずみ硬化時のひずみ T.S. : 引張強さ $\varepsilon \mathbf{u}:$ T.S.時のひずみ Y.R. : 降伏比 EL. : 破断伸び

表 4 シャルピー衝撃試験結果

$\mathrm{vEo}=0^{\circ} \mathrm{C}$ 吸収エネルギー $\mathrm{vBo}=0^{\circ} \mathrm{C}$ 脆性破面率 $\mathrm{Tre}=$ エネルギー遷移温度 $\mathrm{Trs}=$ 脆性破面遷移温度

\section{3.実倹結果}

\section{1 破嘖性状}

亀裂進展摸式図を図 3 に、破面写真を写真 $1 、$ 写真 2 に示す。梁 フランジの $\mathrm{vEo}$ が低い鋼材もあったが、スカラップ端部を起点と する脆性破壊は見られなかった。Cn0 を除く全ての試験体は、梁フ ランジ溶接止端部のフランジ幅端部より溶接熱影響部に沿って延性 的に亀裂が進展し、延性亀裂の先端より脆性破壊した。 $\mathrm{Cn} 0$ は溶接 初層部近傍から脆性破壊している。欠陥の有無について詳細な確認 は行っていないが、目視で判断できるような明らかな欠陥は存在し ていない。脆性的な亀裂（小さな脆性破面も含む）の起点位置によ り、破壊性状を 2 つに分類した。

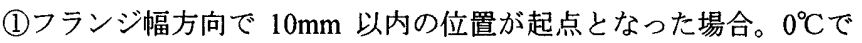
載荷した多くの試験体がこれにあたる。

(2)フランジ幅方向で $10 \mathrm{~mm}$ 以上の位置が起点となった場合。常温 で載荷した全ての試験体がこれにあたる。なお、Fn1, Hn1 はフ ランジ断面の $50 \%$ 程度まで延性的な亀裂が進展している。

$\mathrm{Fn} 1, \mathrm{Hn} 1$ の $\mathrm{P}-\delta$ 曲線は、最大変位時の荷重がサイクルを增す と徐々に低下し、破断に至るサイクルでは明らかに荷重が低下して いる。耐力は延性的な破壊に支配されたといえる。Cn1, En1 のP - $\delta$ 曲線についても同様の傾向が伺える。また、破壊性状が(2)の試 験体は、破壊性状が(1)の試験体に比べて変形量が大きい。

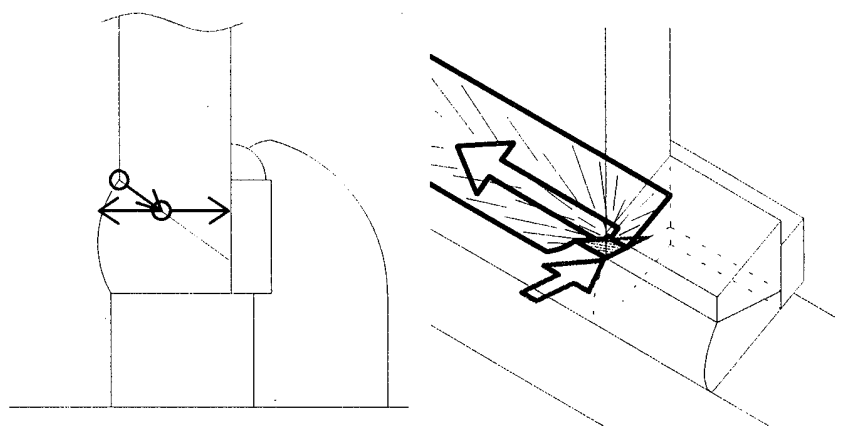

図 3 亀裂進展状況

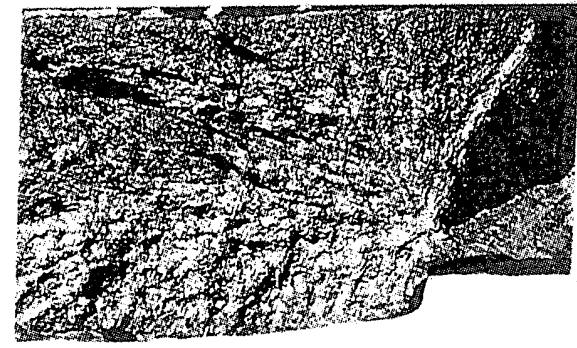

写真 1 (Cs0)

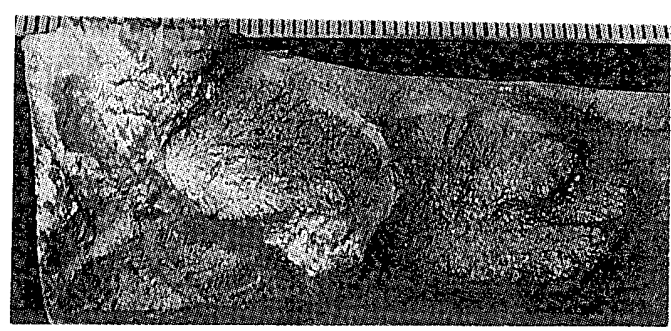

写真 $2(\mathrm{Fn} 1)$ 

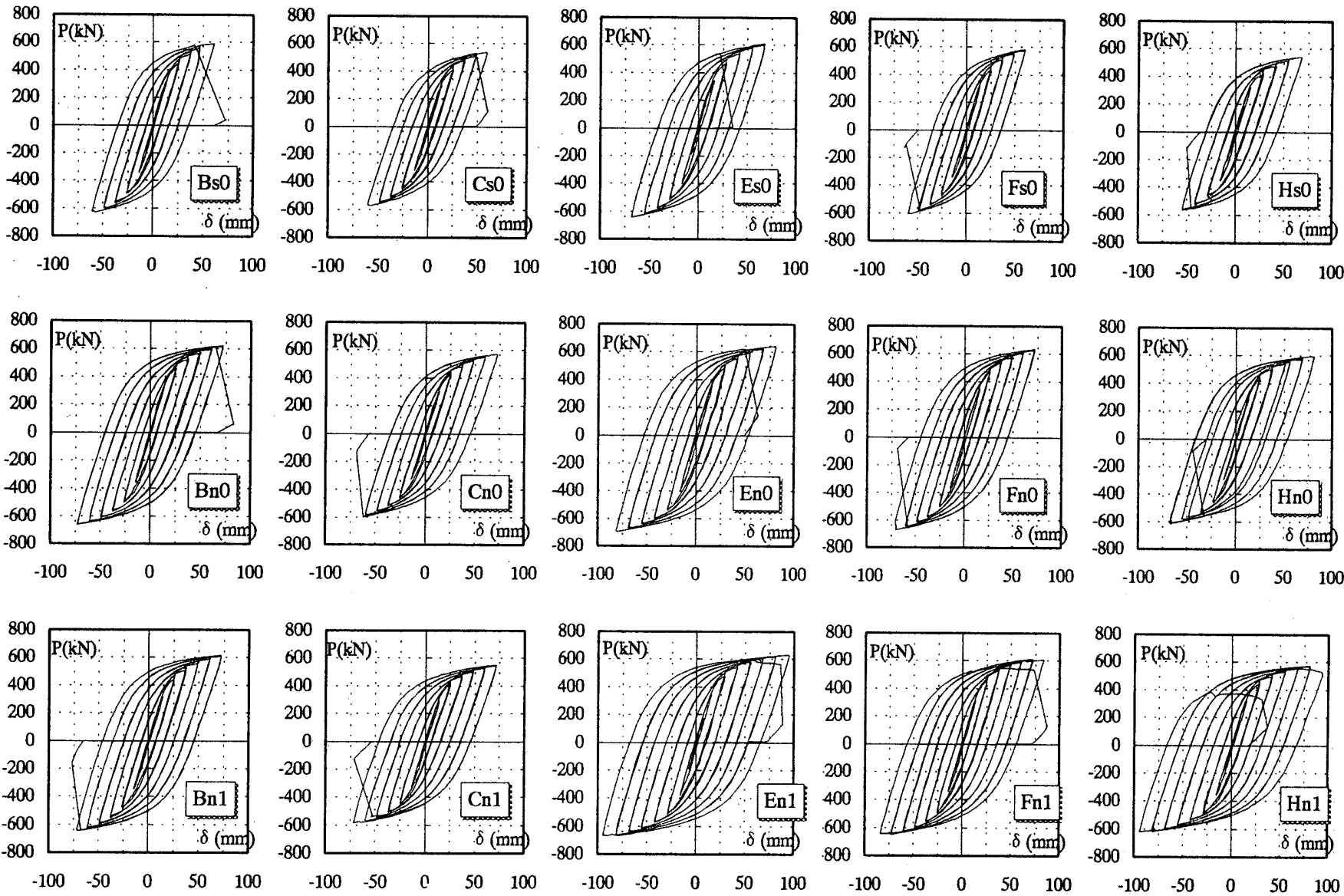

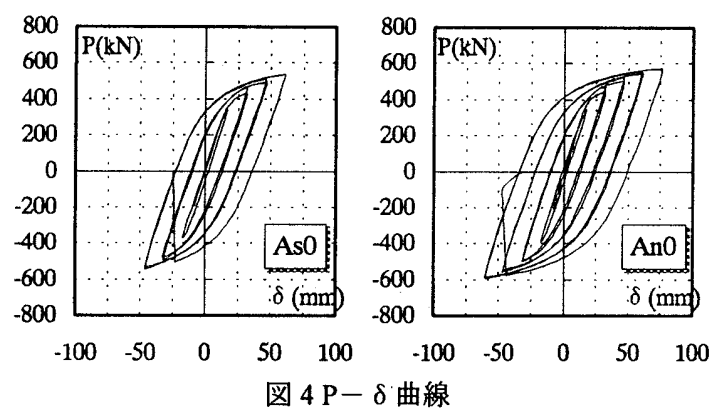

3.2 スケルトン曲瀪と变形能力の指標

荷重 $(\mathrm{P})$-変形 $(\delta)$ 関係を図 4 に示す。 $\mathrm{P}-\delta$ 曲線より求めた、 スケルトン曲線と累積塑性変形量の算出方法を、図 5 に示す。スケ ルトン曲線は $\mathrm{P}-\delta$ 曲線において、荷重が前ループの最大值を超え た分の $\mathrm{P}-\delta$ 曲線を累積して求めた。実験結果一覧を表 5 に示す。

接合部の変形能力を比較する場合、図 5 に示すようなスケルトン 曲線から求めたエネルギー（Ws）と、 $\mathrm{P}-\delta$ 曲線の各ループから求 めたエネルギーの累積值 $(\Sigma W)$ が考えられる。エネルギーは部材 の断面形状、梁長さの影響を受けるため、それらを無次元化した值 を指標とする場合が多い。本実験は、式 3、式 4 により求めた、 s、 $\eta \mathrm{w}$ によって結果を検討する。また、計算値を求める際の鋼材 の降伏応力を、各鋼材の Y.P.によらず一定 ( $\mathrm{F}$ 值 $\left.=325 \mathrm{~N} / \mathrm{mm}^{2}\right)$ とし て全塑性耐力 $\mathrm{cPpF} 、 \mathrm{cPpF}$ 時の曲げ変形量 $\mathrm{c} \delta \mathrm{pF}$ を求めた。 $\mathrm{cPpF}$, $\mathrm{c} \delta \mathrm{pF}$ を用いて、式 5、式 6 により求めた $\eta \mathrm{sF} 、 \eta \mathrm{wF}$ についても検 討を行う。 $\eta \mathrm{sF} 、 \eta \mathrm{wF}$ は、機械的性質の違いによって算出される 値の大きさが影響を受けない、部材の断面形状を無次元化した、変
形能力を評価する指標である。

$$
\begin{array}{lc}
\eta_{\mathrm{S}}=\mathrm{W}_{\mathrm{S}} / \mathrm{C}_{\mathrm{C}} \mathrm{P}_{\mathrm{P}} \times{ }_{\mathrm{C}} \delta_{\mathrm{P}} \cdots \text { 式3 } & \eta_{\mathrm{W}}=\Sigma \mathrm{W} / \mathrm{C}_{\mathrm{P}} \mathrm{P}_{\mathrm{C}} \delta_{\mathrm{P}} \cdots \cdot \text { 式4 } \\
{ }_{\mathrm{C}} \mathrm{P}_{\mathrm{P}}=\mathrm{Z}_{\mathrm{P}} \times \mathrm{Y} \cdot \mathrm{P} / \mathrm{L} & \mathrm{L}: \text { 梁長さ }(1900 \mathrm{~mm}) \\
\eta_{\mathrm{S}} \mathrm{F}=\mathrm{W}_{\mathrm{S}} /{ }_{\mathrm{C}} \mathrm{P}_{\mathrm{P}} \mathrm{F} \times{ }_{\mathrm{C}} \delta_{\mathrm{P}} \mathrm{F} \cdots \text { 式5 } & \eta_{\mathrm{W}} \mathrm{F}=\Sigma \mathrm{W} /{ }_{\mathrm{C}} \mathrm{P}_{\mathrm{P}} \mathrm{F} \times{ }_{\mathrm{C}} \delta_{\mathrm{P}} \mathrm{F} \cdot \text { 式6 } \\
{ }_{\mathrm{C}} \mathrm{P}_{\mathrm{P}} \mathrm{F}=\mathrm{Z}_{\mathrm{P}} \times 325 / \mathrm{L} &
\end{array}
$$

\section{4.考察}

\section{1 ひずみ性状}

各試験体で設定変位が異なるため、荷重一ひずみ（ $\varepsilon$ ）曲線から 図 5 に示すスケルトン曲線の算出方法で、荷重一スケルトンひずみ $(\varepsilon \mathrm{s})$ 曲線を求めた。 $\mathrm{P}-\varepsilon \mathrm{s} 、 \mathrm{P}-\delta \mathrm{s}$ の関係から得られた $\varepsilon \mathrm{s}-\delta$ $s$ 曲線の一例 $(\mathrm{Cs} 0$ の $70 \mathrm{~mm})$ を図 6 に示す。 $\varepsilon \mathrm{s}-\delta \mathrm{s}$ 曲線で $\delta \mathrm{s}$ が $45 \mathrm{~mm}(4 \mathrm{c} \delta \mathrm{pF})$ 時の $\varepsilon \mathrm{s}$ を各試験体で比較した。 $\delta \mathrm{s}=45 \mathrm{~mm}$ は、 延性き裂の影響によるひずみの低下がなく、ひずみゲージが信頼で きる範囲である。比較に用いたひずみゲージの貼付位置を図 7 に示 
表 5 実験結果一覧

\begin{tabular}{|c|c|c|c|c|c|c|c|c|c|c|c|c|c|c|c|c|c|}
\hline & \multirow{2}{*}{$\begin{array}{r}\text { Pmax } \\
(\mathrm{kN}) \\
\end{array}$} & \multirow{2}{*}{$\begin{array}{l}\delta \mathrm{max} \\
(\mathrm{mm})\end{array}$} & \multirow{2}{*}{$\begin{array}{c}\delta \mathrm{s} \\
(\mathrm{mm})\end{array}$} & \multirow{2}{*}{ Ws } & \multirow{2}{*}{$\Sigma \mathrm{W}$} & \multirow{2}{*}{$\begin{array}{c}\delta \mathrm{t} \\
(\mathrm{mm})\end{array}$} & \multicolumn{5}{|c|}{ 素材試験結果で整理 } & \multicolumn{5}{|c|}{ ※F值(3.3)で整理 } & \multirow{2}{*}{$\begin{array}{l}\text { 破壊 } \\
\text { 性状 }\end{array}$} \\
\hline & & & & & & & $\mathrm{cPp}$ & $c \delta p$ & $\eta \mathrm{s}$ & $\eta \mathrm{w}$ & $\alpha$ & $\mathrm{cPpF}$ & $\mathrm{c} \delta \mathrm{pF}$ & $\eta \mathrm{sF}$ & $\eta \mathrm{wF}$ & $\alpha \mathrm{F}$ & \\
\hline As0 & -546 & -46.3 & -42.0 & 20075 & 81999 & -194.9 & 439 & 16.13 & 2.8 & 11.6 & 1.2 & \multirow{3}{*}{342} & \multirow{3}{*}{12.56} & 4.7 & 19.1 & 1.6 & (1) \\
\hline $\mathrm{Cs} 0$ & 538 & 59.8 & 54.9 & 26038 & 20926 & 289.7 & 420 & 15.43 & 4.0 & 18.6 & 1.3 & & & 6.1 & 28.2 & 1.6 & (1) \\
\hline $\mathrm{Hs} 0$ & -567 & -54.8 & -59.3 & 29247 & 133808 & -304.1 & 434 & 15.92 & 4.2 & 19.4 & 1.3 & & & 6.8 & 31.2 & 1.7 & (1) \\
\hline Bs0 & 587 & 60.9 & 59.7 & 31025 & 128344 & 278.8 & 404 & 13.65 & 5.6 & 23.3 & 1.5 & \multirow{3}{*}{382} & \multirow{3}{*}{12.91} & 6.3 & 26.0 & 1.5 & (1) \\
\hline Es0 & 610 & 67.8 & 66.0 & 35827 & 191792 & 408.0 & 402 & 13.60 & 6.5 & 35.0 & 1.5 & & & 7.3 & 38.9 & 1.6 & (1) \\
\hline Fs0 & -608 & -59.2 & -57.2 & 29957 & 146033 & -322.3 & 391 & 13.22 & 5.8 & 28.3 & 1.6 & & & 6.1 & 29.6 & 1.6 & (1) \\
\hline An0 & -594 & -60.8 & -67.5 & 35434 & 160711 & -349.4 & 439 & 16.13 & 5.0 & 22.7 & 1.4 & \multirow{3}{*}{342} & \multirow{3}{*}{12.56} & 8.2 & 37.4 & 1.7 & (2) \\
\hline $\mathrm{Cn} 0$ & -600 & -69.0 & -65.9 & 34208 & 182781 & -405.3 & 420 & 15.43 & 5.3 & 28.2 & 1.4 & & & 8.0 & 42.6 & 1.8 & (1) \\
\hline $\mathrm{Hn} 0$ & -615 & $\begin{array}{l}-67.7 \\
\end{array}$ & -70.0 & 37730 & 196350 & -417.8 & 434 & 15.92 & 5.5 & 28.5 & 1.4 & & & 8.8 & 45.7 & 1.8 & (1) \\
\hline Bn0 & 623 & 72.3 & 90.0 & 50271 & 272380 & 544.8 & 404 & 13.65 & 9.1 & 49.4 & 1.5 & \multirow{3}{*}{382} & \multirow{3}{*}{12.91} & 10.2 & 55.2 & 1.6 & (1) \\
\hline En0 & 642 & 81.2 & 85.7 & 49216 & 265414 & 526.0 & 402 & 13.60 & 9.0 & 48.5 & 1.6 & & & 10.0 & 53.8 & 1.7 & (1) \\
\hline Fn0 & -674 & -70.5 & -72.0 & 42081 & 246618 & -487.4 & 391 & 13.22 & 8.1 & 47.7 & 1.7 & & & 8.5 & 50.0 & 1.8 & (1) \\
\hline $\mathrm{Cnl}$ & -585 & \begin{tabular}{|l|}
-71.4 \\
\end{tabular} & -66.6 & 34035 & 220174 & -497.4 & 420 & 15.43 & \begin{tabular}{l|l}
5.2 \\
\end{tabular} & 34.0 & 1.4 & \multirow{2}{*}{342} & \multirow{2}{*}{12.56} & 7.9 & \begin{tabular}{|l|}
51.3 \\
\end{tabular} & 1.7 & (2) \\
\hline $\mathrm{Hn} 1$ & 574 & 94.1 & 99.6 & 52061 & 352284 & 767.6 & 434 & 15.92 & 7.5 & 51.1 & 1.3 & & & 12.1 & 82.0 & 1.7 & (2) \\
\hline $\mathrm{Bn} 1$ & -646 & -71.5 & -81.3 & 45343 & 255987 & -426.5 & 404 & 13.65 & 8.2 & 46.4 & 1.6 & \multirow{3}{*}{382} & \multirow{3}{*}{12.91} & 9.2 & 51.9 & 1.7 & (2) \\
\hline En1 & 631 & 94.7 & 101.1 & 57762 & 413220 & 814.8 & 402 & 13.60 & 10.5 & 75.5 & 1.6 & & & 11.7 & 83.8 & 1.7 & (2) \\
\hline Fn1 & 612 & 83.1 & 71.8 & 39490 & 330447 & 675.5 & 391 & 13.22 & 7.6 & 63.9 & 1.6 & & & 8.0 & 67.0 & 1.6 & (2) \\
\hline
\end{tabular}

$P \max$ :最大荷重 $\delta \max$ :最大変位 $\delta \mathrm{s}$ : スケルトン変位(塑性) Ws:スケルトン吸収エネルギー $\Sigma \mathrm{W}$ : 累積吸収エネルギー $\delta \mathrm{t}$ :累積塑性変形量 $\mathrm{cPp}$ :全塑性耐力 $\mathrm{c} \delta \mathrm{p}$ :全塑性耐力時の曲 げ変形量 $\quad \eta \mathrm{s}: \mathrm{Ws} / \mathrm{cPp} \cdot \mathrm{c} \delta \mathrm{p} \quad \eta \mathrm{w}: \Sigma \mathrm{W} / \mathrm{cPp} \cdot \mathrm{c} \delta \mathrm{p} \quad \alpha: \mathrm{Pmax} / \mathrm{cPp}$ ※ Fがある指標は降伏志力にF値 $(325 \mathrm{~N} / \mathrm{mm} 2)$ を用いて算出した

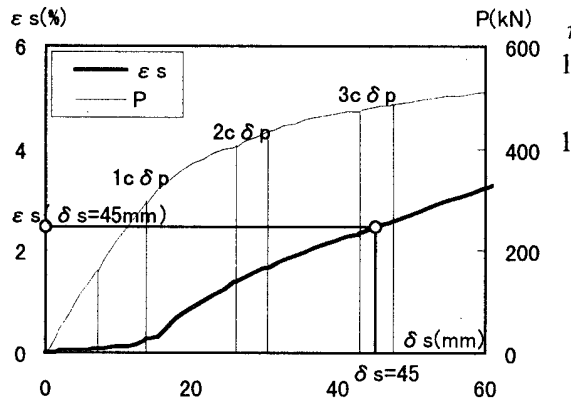

図 $6 \varepsilon \mathrm{s}-\delta \mathrm{s}$ 曲線 $(\mathrm{Cs} 0,70 \mathrm{~mm})$

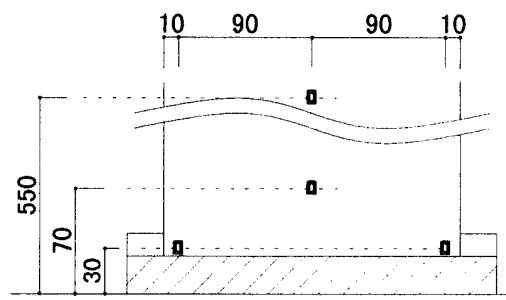

図 7 ゲージ貼付位置

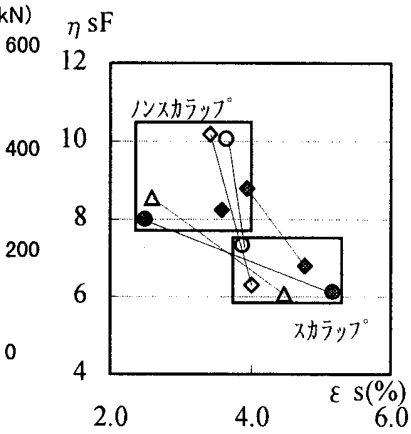

(a) $30 \mathrm{~mm} 2$ 枚の平均

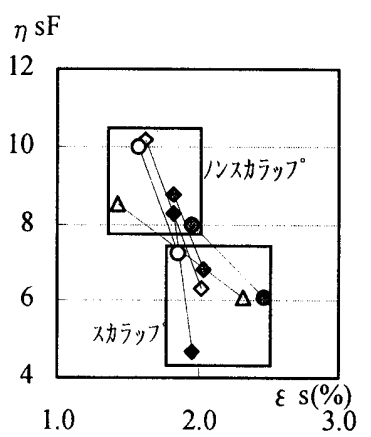

(b) $70 \mathrm{~mm}$

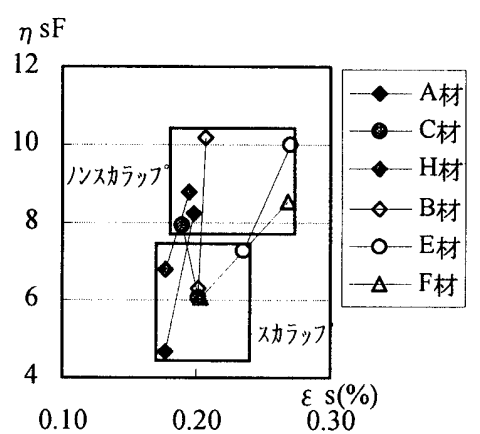

(c) $550 \mathrm{~mm}$

図 $8 \eta \mathrm{sF}-\varepsilon \mathrm{s}$ 関倸 $\left(0^{\circ} \mathrm{C}\right.$ スカラップと $0^{\circ} \mathrm{C}$ ノンスラップ)

す。梁端部のひずみと して、破壊起点近傍の 応力集中箇所であり破 壊に影響すると考えら れる $30 \mathrm{~mm}$ の位置の 平均と、溶接の余盛形

状や貼付位置の誤差などの影響が少ないと考えられる $70 \mathrm{~mm}$ の位 置に貼付したゲージの值を採用した。また、塑性域の広がりを確認 する目的で、 $550 \mathrm{~mm}$ の位置に貼付したゲージの值も検証した。

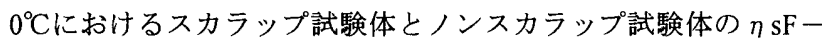
$\varepsilon s$ 関釈を図 8 に示す。図 8 (a)，(b) より、30 $\mathrm{mm}$ の 2 枚の平均 と 70mmについて、 $\varepsilon \mathrm{s}$ が大きいほど $\eta \mathrm{sF}$ が小さくなる傾向があり、 ノンスカラップ試験体はスカラップ試験体に比べて \& s が小さい傾 向にある。また、梁材の降伏比が低い試験体は $\varepsilon \mathrm{s}$ が小さい傾向を 示す。特に、30mm のゲージについてスカラップ試験体が、 $70 \mathrm{~mm}$ のゲージについてノンスカラップ試験体が顕著である。梁が同一量 変形した時点での梁端部のひずみが小さいほど、変形能力は大きく なるといえる。図 8 (c) $550 \mathrm{~mm}$ について、多くの試験体で $\varepsilon \mathrm{s}$ は $0.2 \%$ 以下（弾性域）であるが、図 8（a)，（b）とは逆に、 $\varepsilon \mathrm{s}$ が大きい
ほど $\eta \mathrm{sF}$ が大きくなる傾向が伺える。特に降伏比の低い $\mathrm{E}$ 材、F 材のノンスカラップ試験体が大きい。降伏比の低い試験体および， ンスカラップ試験体は、降伏比の高い試験体およびスカラップ試験 体に比べて塑性域が長手方向に広がり、梁端部付近のひずみは小さ くなる傾向があるといえる。

\section{2 梁材の機械的性質の影箘}

スケルトン曲線より求めた Ws を素材試験結果の Y.P.により無次 元化した $\eta \mathrm{s}$ と材料特性の関係について以下に示す。材料特性をパ ラメータとする場合、鋼材の降伏点、引張強さ、降伏比、一様伸び、 ひずみ硬化率などが考えられる。本実験では梁材の材料特性として、 素材試験の結果をもとに、下降伏点（lowY.P.）、真応力の下降伏点 と引張強さの和の $1 / 2$ とした值（ $\sigma$ flow $=($ lowY.P.+T.S. $)$ 12)、降 伏比（Y.R.）、ひずみ硬化率と対応する真応力の下降伏点と引張強 さ、一様伸びによる直線の傾き（Ho）について検討した。 $\eta \mathrm{s}$ とそ れぞれの関係を図 9〜図 12 に示す。図中の直線は梁端ディテール ごとのプロット点を最小二乗法により直線近似した結果である。

図 9〜図 11 より、lowY.P.、。 flowおよびY.R.と $\eta$ s には相関があ る。lowY.P、 $\sigma$ flow および Y.R.が小さくなるに従って、 $\eta \mathrm{s}$ は大き くなる傾向があり、最大と最小の差は $3 \sim 4$ 程度である。また、同 


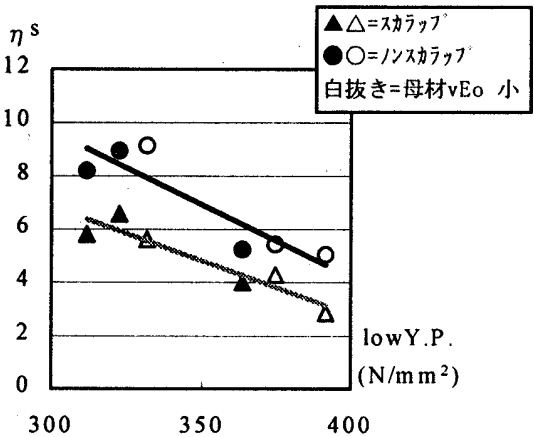

図 $9 \eta \mathrm{s}-$ lowY.P.関倸

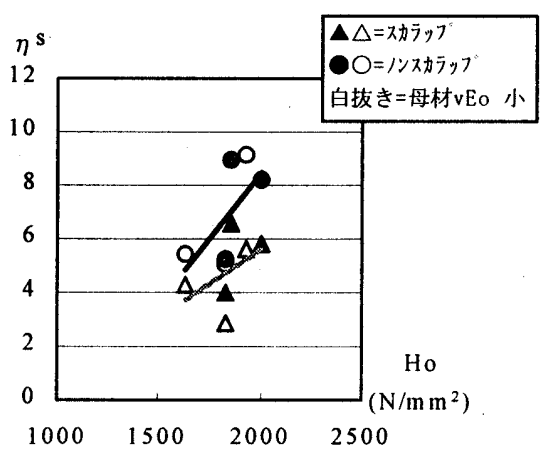

図 $12 \eta \mathrm{s}-\mathrm{Ho}$ 関係

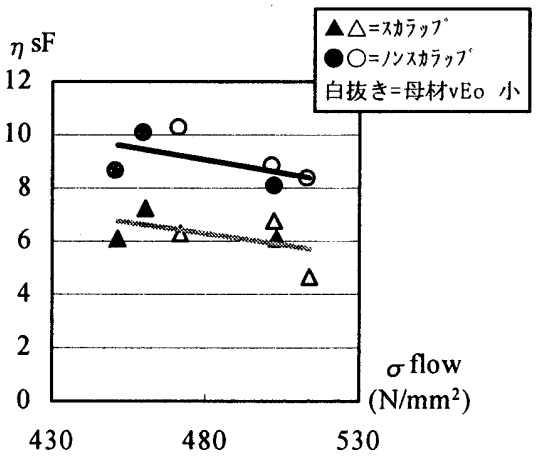

図 $15 \eta \mathrm{sF}-\sigma$ flow 関倸

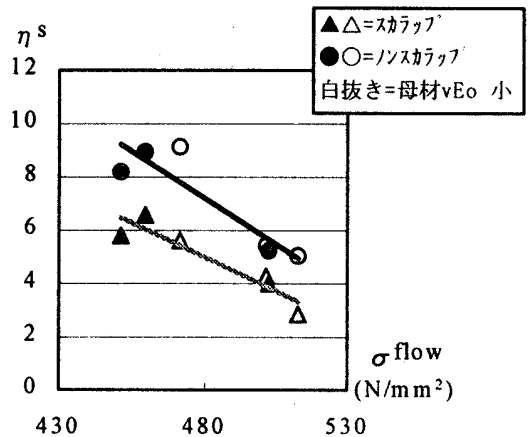

図 $10 \eta \mathrm{s}-\sigma$ flow 関係

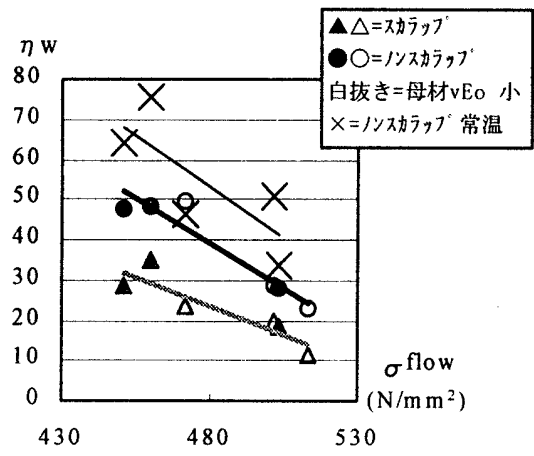

図 $13 \eta w-\sigma$ flow 関係

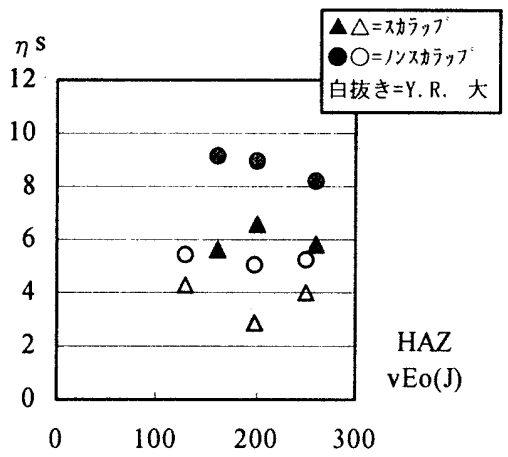

図 $16 \eta \mathrm{s}-\mathrm{HAZvEo}$ 関倸

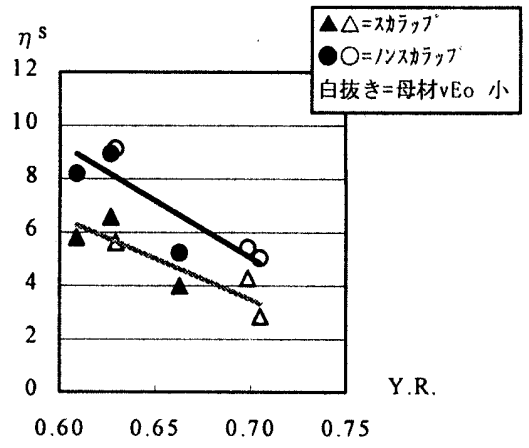

図 $11 \eta \mathrm{s}-$ Y.R.関係

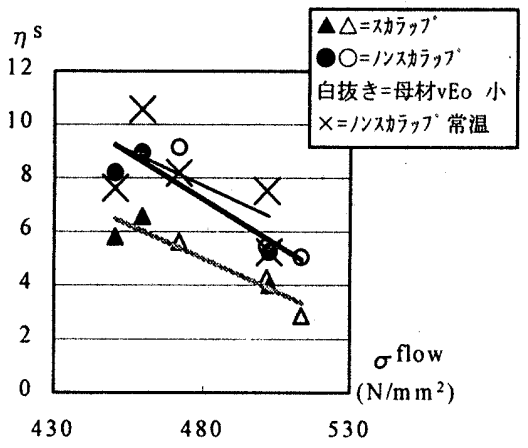

図 $14 \eta \mathrm{s}-\sigma$ flow 関係

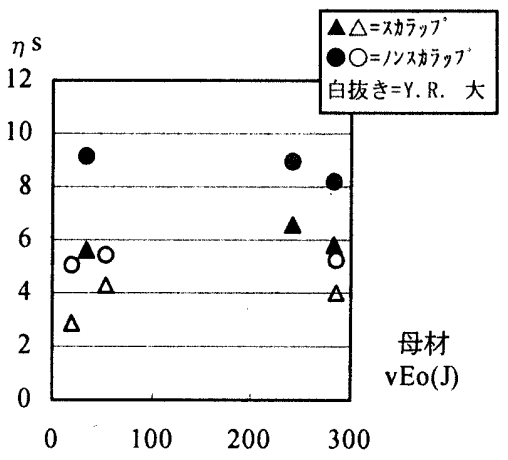

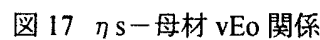

じく図 12 について Ho が大きくなるに従って、 $n \mathrm{~s}$ は大きくなる傾 向がある。母材 vEo が小さい試験体は白抜きで示したが、 $\eta \mathrm{s}$ と機 械的性質の関係で示された傾向に母材 vEo の差違による影響はみ られない。

同一の鋼材を梁に用いた場合では、ノンスカラップ試験体がスカ ラップ試験体より $\eta \mathrm{s}$ で 2 3 程度大きい。ノンスカラップ試験体 とスカラップ試験体の優位性については、既往の研究 7.8) と同じ傾 向を示している。パラメータが $\eta \mathrm{s}$ に与える影響の度合を比較する と、機械的性質は 3〜4で、梁端ディテールは 2〜3である。機械的 性質の方が $\eta \mathrm{s}$ にやや大きく影響している。

常温における試験体について、累積塑性吸収エネルギー（ を無次元化した $\eta \mathrm{w}$ と $\eta \mathrm{s}$ で考察する。 $\eta \mathrm{w}-\sigma$ flow 関係、 $\eta \mathrm{s}-\sigma$ flow 関係を図 13、図 14 に示す。 $\eta \mathrm{w} も \eta \mathrm{s}$ と同様に $\sigma$ flow が小さ くなるに従い大きくなる傾向がある。 $0^{\circ} \mathrm{C} て ゙$ 載荷されたスカラップ 試験体とノンスカラップ試験体は図 10 の $\eta \mathrm{s}$ - $\sigma$ flow 関係とよく対 応しているが、常温で載荷されたノンスカラップ試験体については $\eta \mathrm{s}-\sigma$ flow 関係と異なる傾向がみられる。 $\eta \mathrm{w}$ で評価すると、常
温の試験体と $0^{\circ} \mathrm{C}$ 試験体の差が大きくなる。また、機械的性質と の相関性は $\eta \mathrm{w}$ の方が高い。Ws は各載荷ループ毎の荷重上昇率が 値に影響するため、荷重が低下する場合は $\eta \mathrm{s}$ が小さくなる。常温

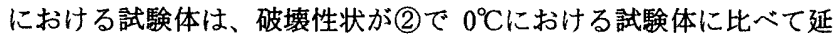
性破面が大きく、荷重が低下している。変形能力を評価する指標に は、破壊性状の違いも影響する。

Ws を F 值により無次元化した $\eta \mathrm{sF}$ と $\sigma$ flow との関係を図 15 に 示す。 $\eta \mathrm{s}$ は無次元化の際にパラメータである降伏点が影響し、図 9〜図11 は右下がりになる傾向が出る。 $\eta \mathrm{sF}$ は算出の際にパラメ 一タの影響を受けないため、梁端接合部が吸収したエネルギーを等 価な値で比較することができる。図 15 は、図 9〜11 ほど顕著な傾 向ではないが右下がりを示しており、 $\eta \mathrm{sF}$ も flow が小さくなる に従い大きくなる傾向があるといえる。

\section{3 梁材の vEoの影㕣}

$\mathrm{HAZ}$ 部より採取した試験片による $\mathrm{vEo}(\mathrm{HAZvEo})$ 及び梁フラン ジの vEo と、 $\eta \mathrm{s}$ の関係を図 16、図 17 に示す。 $\eta \mathrm{s}$ と vEo には顕 著な傾向が見られない。本実験において、破壊起点は溶接止端部よ 
り延性的に進展した亀裂の先端より破壊しているため、HAZvEoの 方が破壊に影響すると考えられる。 2.2 で述べたが、フランジ材の vEo が小さい梁材は、HAZvEo の方が大きくなり、全梁材のうち $\mathrm{HAZvEo}$ が最低の $\mathrm{H}$ 材は $0^{\circ} \mathrm{C} て ゙$ 吸収エネルギーが $130 \mathrm{~J}$ 、脆性破面 率が $50 \%$ 程度である。vEo が変形能力に影響した文献 16),17)の vEo はいずれも50J 以下と低い值であった。本実験で vEo が変形能力に あまり影響しなかった理由の一つとして、破壊起点近傍の HAZvEo が比較的高いことが挙げられる。

\section{5.まとめ}

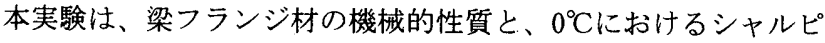
一吸収エネルギーが、柱梁溶接接合部（梁せい $400 \mathrm{~mm}$ ，フランジ 厚 $21 \mathrm{~mm}, 25 \mathrm{~mm}$ ) の変形能力に与える影響を、6 種類の鋼材を使用 したスカラップ試験体とノンスカラップ試験体を用いて検討した。 なお、破壊起点である熱影響部の勒性が最も低い試験体の vEo は 130Jである。得られた結果を以下に示す。

1)梁フランジの機械的性質は変形能力に影響を与える。降伏点、 $\sigma$ flow および降伏比が低いほど変形能力は高くなる。

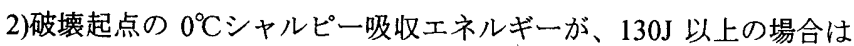
変形能力にほとんど影響を与えない。

3)降伏比が低い試験体は降伏比が高い試験体に比べて塑性域が広が

り、梁端部のスケルトンひずみは小さい傾向を示す。

4)ノンスカラップ試験体の方がスカラップ（スカラップ底のアール は $10 \mathrm{~mm}$ ) 試験体に比べて変形能力に優れるが、変形能力に及ぼ 寸影響はスカラップの有無による影響に比べて梁材の機械的性質 の違いによる影響の方がやや大きい。

5)延性破面の割合が大きい試験体は、スケルトン吸収エネルギー

（Ws）より累積塑性吸収エネルギー（ $\mathrm{WW}$ )で評価した方が機 械的性質との相関性が高い。

なお、本研究は限られたディテール、部材寸法、載荷パターンに より行われた実験であり、それら因子が破壊に与える影響をさらに 検討する必要がある。また、破壊起点を詳細に調查し、破壊起点の 勒性值を算出する試験方法の検討を含めて、研究を進める必要があ る。

\section{謝辞}

本研究の一部は平成 9 10 年度文部省科学研究費補助金 : 基盤研 究（B）(2)（課題番号：09450203, 研究代表者：中込忠男）によ りました。供試体製作にあたり株式会社宮地鐵工所の吉川薫様、実 験を進めるにあたり神奈川大学の村井正敏先生の御協力を得ました。 併せて感謝の意を表します。

\section{参考文献}

1)加藤勉・青木博文 : 応力集中を有寸る変断面材の伸び能力と降伏比, 日本 建築学会論文報告集, 第 159 号, pp. $25 \sim 30,1969.5$

2)青木博文 · 加藤勉 - 難波恒夫 ·佐藤亘宏 : 変断面鋼板引張材の変形能力と 素材の力学的特性, 日本建築学会論文報告集, 第 320 号, pp.36 42, 1982.10 3)青木博文・加藤勉 - 難波恒夫 - 佐藤亘宏 : 変断面鋼板引張材の変形能力に 及ぼす試験温度・ひずみ速度の影響，日本建築学会論文報告集，第 322 号， pp.11 17, 1982.12

4)青木博文・村田耕司：構造用鋼材の降伏点，引張強さおよび降伏比に関す

る統計的調査, 日本建築学会論文報告集, 第 335 号, pp.157〜168, 1984.1 5)青木博文 - 増田正之 : 素材引張試験結果による構造用鋼材の力学的性質に 関寸る統計的調査，日本建築学会構造系論文報告集，第 358 号, pp.94〜102, 1985.12

6)藤本盛久・藤盛紀明・中込忠男・多賀雅秦 : エンドタブ・裏当て金を有寸 る柱梁接合部の破壊性上に関する研究，日本建築学会論文報告集、第 334 号, PP. $58 \sim 68,1983.12$

7)中込忠男・矢部喜堂・坂本真一 : 梁スカラッブの有無が H 形断面柱に溶接 接合される $\mathrm{H}$ 形鋼梁端部の力学的性状に及ぼす影響, 日本建築学会構造系 論文報告集，第 432 号，pp.51 59, 1992.2

8)中込忠男 - 藤田哲也 ·南圭祐・李建 - 村井正敏 : 柱梁溶接接合部における ノンスカラッブエ法梁端ディテールに関する実験的研究, 日本建築学会構 造系論文報告集，第 498 号, pp.145 151，1997.8

9)日本建築学会近畿支部鉄骨構造部会 : 通しダイアフラム形式で角型形鎙管柱に 接合されるH形鋼梁の塑性変形能力に関寸る実大実験報告書, 1997.7 10)久野和利・淞井千秋：鋼材の降伏比が材端溶接部を含む梁部材の変形能 力に及ぼす影響, 日本建築学会大会学術講演梗概集(中国), pp.1353 1354, 1990.10

11)日本建築学会近畿支部鉄骨構造部会：1995 年兵庫県南部地震鉄骨造建築 物被害調查報告書, 1995.5

12）藤本盛久・青木博文・中込忠男・西沢淳 : 電炉広幅平鋼及び電炉厚鋼板 （SM490A）を用いた柱・梁接合部の実験，日本鉬構造協会鋼構造論文集， Vol.1 No.4, pp.127 142, 1994.12

13）藤本盛久・青木博文・中込忠男・西沢淳：電炉広幅平鋼及び電炉厚鋼板 （SM490A）を用いた柱・梁接合部の破壊性状と素材特性の関係，日本錀 構造協会鋼構造論文集, Vol.1 No.4, pp. 143〜157, 1994.12

14)藤本盛久・青木博文・中込忠男 - 西沢淳 : 電炉広幅平鎆及び電炬厚鋼板 （SM490A）を用いた柱・梁接合部の塑性変形能力確保のための鋼材の性 能，日本鋼構造協会鋼構造論文集，Vol.2 No.8，pp.61～72, 1995.12 15)藤本盛久 - 青木博文・ 中込忠男・西沢淳 : 電炉広幅平鋼（SM490A）を用 いた柱・梁接合部の仕ロディテールの改良と塑性変形能力の向上, 日本鋼 構造協会鎆構造論文集, Vol.3 No.9, pp.19～30，1996.3

16)中込忠男 - 藤本盛久. 青木博文・西沢淳・南圭祐 : $500 \mathrm{~N} / \mathrm{mm} 2$ 級鋼の板厚 · 強度と必要勒性, 日本建築学会大会学術講演梗概集 (北海道), pp.619 620, 1995.8

17)田淵基嗣・金谷 弘・園田隆一：鍋管柱・梁接合部の力学性状に与える接 合部詳細の影響(その 8 梁フランジの脆性破壊に与える諸因子の影響)，日 本建築学会大会学術講演梗概集 (北陸), pp.1539 1540, 1992.8

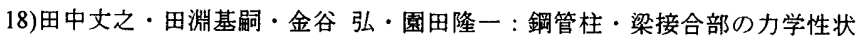
に与える接合部詳細の影響(その 9 スカラッブ形状及び梁の材質の影響), 日本建築学会大会学術講演梗概集 (関東), pp.1245 1246, 1993.8 19)宮田隆志 - 大塚昭夫 ·三林雅彦・土師利昭 - 粟飯原周二 : Local Fracture Criterionによる破壊じん性の推定, 材料, Vol.37, No.419, pp.897-903, 1988.8 20)宮田隆志・大塚昭夫・大竹剛志・鉿木康志 : 鋼の八き開破壊じん性と引 張強度特性との相関, 材料, Vol.39, No.446, pp.1549-1555, 1990.11 21)宿野部勇祐 - 中込忠男 - 村井正敏 - 的場耕 - 會田和広 - 白井嘉行 : 梁材 の機械的性質が柱梁溶接接合部の変形能力に与える影響に関する実験的研 究, 日本建築学会大会学術講演梗概集（中国）, pp.529～530，1999.9 